\title{
Legal Protection Mandatory To Pay Tax In Tax Disputes
}

\author{
Muljadi Djaja, SE.Ak, SH, CPA, CA, BKP \\ Institut STIAMI \\ kkpmuljadi@yahoo.com
}

DOI: 10.29322/IJSRP.11.07.2021.p11582

http://dx.doi.org/10.29322/IJSRP.11.07.2021.p11582

\begin{abstract}
Legal protection in the tax sector is a form of protection for the rights and obligations of taxpayers in tax disputes that can be protected by law in order to obtain legal certainty, so that they can be fought for. This study aims to determine the legal protection provided to taxpayers in tax disputes for filing PBB at KPP X. The results of this study indicate that the legal protection sought by KPP X and the ranks of tax officials above has not been maximized. As a recommendation, it is necessary to have a forum or forum formed by KPP X to coordinate in each kelurahan in the working area of KPP X, to accommodate complaints experienced by PBB taxpayers which can actually be used as socialization activities on tax regulations
\end{abstract}

Keywords: Taxpayer Legal Protection, Tax Dispute

\section{INTRODUCTION}

Tax is one of the sources of state treasury income which is ultimately used for development with the ultimate goal of welfare and prosperity of the people. Tax is an obligation that must be paid by every citizen to be responsible for carrying the burden of development for the progress of this nation. However, it cannot be denied that the increasing number of taxpayers and tax bearers, as well as an understanding of their rights and obligations in implementing tax laws and regulations, can trigger an increasing potential for tax disputes which require a fair settlement with a fast, simple and cost-effective process. light, because it requires a means to resolve tax disputes, namely through the Tax Court, where filing a claim for rights through the Tax Court is a form of legal effort as a form of implementation of legal protection for taxpayers and tax bearers Advianto, L. H. S. (2018) states that legal protection for the people can be divided into two types, namely preventive legal protection and repressive legal protection. Preventive legal protection is legal protection where the people are given the opportunity to submit their objections or opinions before a decision is declared. The preventive form aims to prevent disputes from occurring, while on the contrary repressive legal protection aims to resolve disputes. Preventive legal protection means a lot for government actions based on freedom of action, because there is legal protection based on the discretion of Cesariyanto, B. P. (2012).

Before the tax court was established, the media used to resolve tax disputes was the Tax Advisory Council (MPP) which was later replaced by the Tax Dispute Settlement Agency (BPSP) based on Law Number 17 of 1997 concerning the Tax Dispute Settlement Agency. The establishment of BPSP is inseparable from the lengthy process of resolving previous tax disputes, which follows the provisions of Law no. 5 of 1986 concerning the State Administrative Court, which is pursued through the Tax Advisory Council (MPP) which is categorized as an Administrative Appeal in the State Administrative Court system. Although 
the Tax Dispute Settlement Agency (BPSP) was established in 1998, the need to establish a judicial body such as the current Tax Court is reflected in the points of consideration in the Tax Court Law Number 14 of 2002 concerning the Tax Court, it is stated that In the implementation of tax dispute resolution through BPSP there are still legal uncertainties that can lead to injustice, besides that BPSP is not yet a judicial body culminating in the Supreme Court.

(MA), because in this tax justice system, the Supreme Court is not authorized to settle tax disputes, therefore a tax court is needed that is in accordance with the judicial power system in Indonesia and is able to create justice and legal certainty in Indonesia. Law No. 17 of 1997 concerning the Tax Dispute Settlement Agency is considered to contain many weaknesses, both because the regulation is felt to be unfair and does not provide legal certainty and because of the government's desire to accommodate the aspirations of the people who want the terms of appeal not to have to pay off all tax debts Sumantry, D. (2011). To fulfill this expectation on April 12, 2002, the President passed Law no. 14 of 2002 concerning the Tax Court promulgated in the State Gazette of the Republic of Indonesia Year 2002 No. 27.

Although it has undergone several changes, the existence of a tax dispute settlement institution with the issuance of Law no. 14 of 2002 concerning the Tax Court, in fact it still contains a weakness, namely ambiguity regarding the position of the Tax Court in the judicial system in Indonesia. 4 of 2004 concerning Judicial power, it is known that there are 4 (four) court environments, namely: General Courts, Religious Courts, Military Courts, and State Administrative Courts. Meanwhile, in the provisions governing the position of the Tax Court, namely in Article 2 of Law no. 14 of 2002 concerning the Tax Court, it is stated that: "The Tax Court is a judicial body that exercises judicial power for taxpayers or tax insurers seeking justice for tax disputes".

In this provision it is not stated at all that the Tax Court is included in one of the 4 (four) existing judicial environments, as if the Tax Court is an independent judiciary outside of the 4 (four) existing judicial environments. This is different when compared to the juvenile court which formally determines the status of its judicial environment, which can be seen in the provisions of Article 3 of Law No. 3 of 1997 concerning Juvenile Court which states that: General." The same thing can also be found in the regulation of the Commercial Court, Human Rights Court, and other Special Courts which clearly state the status of the judicial environment.

The ambiguity of the position of the tax court in the judicial system in Indonesia can also be seen from the discrepancy between Law no. 9 of 2004 concerning Amendments to Law no. 5 of 1986 concerning the State Administrative Court with Law no. 14 of 2002 concerning the Tax Court. In the explanation of Article 9A of Law no. 9 of 2004 concerning Amendments to Law no. 5 of 1986 concerning the State Administrative Court, has explained the status of the Tax Court by stating that "What is meant by "specialization" is differentiation or specialization in the state administrative court environment, for example the Tax Court." Thus, the law recognizes the tax court as a special court within the state administrative court.

However, with the absence of Law no. 9 of 2004 concerning Amendments to Law no. 5 of 1986 concerning the State Administrative Court in the preamble of Law no. 14 of 2002 concerning the Tax Court as a basis for consideration in the establishment of a tax court, this means that Law no. 14 of 2002 does not need to comply with the provisions of Article 9A of Law no. 9 of 2004 which regulates the position of the tax court as a special court within the administrative court of the State Judge, T. R. (2013). The status of the tax court has not been formally regulated in Law No. 14 of 2002 concerning the Tax Court, leaving a debate about the position of the Tax Court in the judicial system in Indonesia.

Based on the description above, this paper tries to examine theoretically about how the position of the Tax Court in the judicial system in Indonesia and whether Law no. 14 of 2002 can provide legal protection for taxpayers and tax bearers? According to Rochmat Soemitro, 
tax law is a collection of regulations that regulate the relationship between the government as a tax collector and the people as taxpayers. In other words, Rochmat Soemitro said that tax law is a part of public law. On the other hand, Lestari, D. (2018) which states that in the literature it turns out that tax law is part of administrative law which is all legal regulations that regulate all ways of working and implementing as well as the authority of state institutions and their apparatus in carrying out administrative tasks.

\section{LITERATURE REVIEW}

\section{Means of Legal Protection through Tax Court}

Disputes regarding taxation occur due to differences in interpretation or opinion between the Taxpayer and the Tax Insurer on the one hand and the tax authorities on the other regarding tax provisions. The resolution of these differences in opinion or interpretation must lead to fair treatment for both parties. In this case, the taxpayer or the tax insurer can use available legal remedies such as appeals or lawsuits.

a. Appeal

The appeal is a continuation of the dissatisfaction with the objection decision. In a sense, there is no appeal before going through an objection because what is being appealed is an objection decision letter as a form of tax dispute resolution at the Objection Institution level. Thus, the object of dispute at the appeal stage is directed to the objection decision letter issued by the tax official as the deciding party which is considered by the taxpayer or the tax insurer not reflecting justice, expediency, or legal certainty. The object of the dispute at the appeal stage is a continuation of the tax dispute at the objection stage, but what is disputed is the material or content of the said objection decision letter. In order for an appeal to be accepted for examination by the Tax Court, it must first meet the requirements, namely (Arifuddin, A., Widhiyanti, H. N., \& Susilo, H., 2017):

1) An appeal is filed with an appeal letter in the Indonesian language;

2) The appeal letter is addressed to the Tax Court;

3) Contains clear reasons and includes the date of receipt of the decision on the objection being compared;

4) Attach a copy of the decision on the objection being compared;

5) An appeal against the amount of tax payable, has previously been paid fifty percent;

6) An appeal letter is filed within the specified time, except for circumstances beyond his control

7) If the appeal letter is drawn up and signed by the legal counsel for the comparison, it must be accompanied by a valid special power of attorney. The period of time for filing an appeal is a requirement for the validity of an appeal.

Article 35 paragraph (2) of Law no. 14 of 2002 concerning the Tax Court confirms that: "an appeal is filed within three months from the receipt of the decision being appealed, unless otherwise provided for in the tax laws and regulations. The period of three months is calculated from the date the decision is received until the date the appeal letter is sent by the appellant." If the examination of the appeal has been completed and a decision is issued which is deemed not to reflect justice and legal protection, the decision can be submitted for REVIEW at the Supreme Court.

\section{b. Lawsuit}

The lawsuit pursuant to Article 1 point 7 of Law no. 14 of 2002 concerning the Tax Court is "Legal efforts that can be taken by taxpayers or tax insurers against the implementation of tax collection or against decisions that can be filed according to the applicable tax laws and 
regulations". The object of the dispute at this stage is regulated in Article 23 paragraph (2) of Law no. 28 of 2007 concerning the Third Amendment to Law no. 6 of 1983 concerning General Provisions and Tax Procedures which states that: Lawsuits by taxpayers or tax bearers against:

1) Execution of forced warrant, warrant for confiscation, or announcement of auction;

2) Preventive decisions in the context of tax collection;

3) Decisions related to the implementation of tax decisions, other than those stipulated in Article 25 paragraphs (1) and 26; or

4) The issuance of a tax assessment letter or an objection decision letter which is not in accordance with the procedures or procedures stipulated in the provisions of the tax laws and regulations can only be submitted to the tax court.

In addition to the object of the lawsuit that determines the validity, there are also several requirements that must be met for a lawsuit, namely (Arifuddin, A., Widhiyanti, H. N., \& Susilo, H., 2017):

1. The claim is submitted in writing in the Indonesian language;

2. The lawsuit is addressed to the Tax Court;

3. The lawsuit contains clear reasons and includes the date of receipt of the tax invoice or decision being sued;

4. The lawsuit attaches a copy of the document being sued;

5. The lawsuit is filed within the specified period, unless it is in a situation beyond its control

6. If the claim is made and signed by the plaintiff's attorney, the lawsuit must be accompanied by a special valid power of attorney.

If the decision of the Tax Court is deemed not to reflect the existence of justice and legal protection, the decision can be submitted for review to the Supreme Court. Review by the Supreme Court as a legal remedy for the decision of the Tax Court. The review of the decision of the Tax Court to the Supreme Court is a legal means for the Supreme Court to supervise the decision of the Tax Court, considering that the Supreme Court in examining and deciding the Review of the Tax Court decision does not only examine the application of the law. , but includes the facts that occurred during the examination conducted by the panel or single judge Ispriyarso, B. (2015).

After the application for judicial review of the Tax Court's decision to the Supreme Court has fulfilled the reasons and the period for filing it, and is not revoked, the examination is carried out by the Supreme Court. The reasons for the application for judicial review of the decision of the Tax Court as referred to in Article 91 of Law no. 14 of 2004 concerning the Tax Court are as follows:

a) If the decision is based on a lie or trick of the opposing party which is known after the case has been decided or is based on evidence which is later declared false by the criminal judge;

b) If there is new written evidence that is important and decisive; which if known at the trial stage in the Tax Court will result in a different decision;

c) If something has been granted which is not demanded or more than what is demanded, unless it is decided based on Article 80 paragraph (1) letter $\mathrm{b}$ and letter $\mathrm{c}$;

d) If a part of the claim has not been decided without considering the reasons; and

e) If there is a decision that is clearly not in accordance with the provisions of the applicable laws and regulations

The period for submitting the application for judicial review as regulated in Article 92 of Law no. 14 of 2004 concerning the Tax Court which, if examined carefully, the period of the 
application for judicial review requires a maximum period of ninety working days, commencing from:

a. Knowledge of lies or deception or since the decision of the judge of the Criminal Court has permanent legal force as referred to in Article 91 letter a of Law no. 14 of 2002 concerning the Tax Court;

b. The documents of evidence as referred to in Article 91 letter b of Law no. 14 of 2002 concerning the Tax Court which day and date it is found must be declared under oath and ratified by a tax official; and

c. Tax court decisions are sent to the parties as referred to in Article 91 letter c, letter d, and letter e of Law no. 14 of 2002 concerning the Tax Court. Based on Article 90 of Law no. 14 of 2004 concerning the Tax Court, related to legal remedies for judicial review, it is stated that "The procedural law applicable to the judicial review is the procedural law of judicial review as referred to in Law no. 14 of 1985 concerning the Supreme Court except as specifically regulated in this law."

This means that the procedural law of judicial review used is the procedural law of judicial review contained in Law no. 14 of 1985 concerning the Supreme Court as long as it is not specifically regulated by Law no. 14 of 2002 concerning the Tax Court. Examination of the application for review of the decision of the Tax Court by the Supreme Court is an examination that does not require the presence of the disputing parties, but in its examination the Supreme Court has the authority to order the Tax Court to conduct additional examinations of the disputing parties and request additional information and considerations from the Tax Court regarding it can be seen in the provisions of Article 18 of the Supreme Court Regulation No. 3 of 2002 concerning Procedures for Submission of Applications for Review of Tax Court Decisions.

\section{Underpayment Tax Assessment Letter}

Underpaid Tax Assessment is meant by the Self Assessment method, the taxpayer is given and entrusted by law to calculate his own tax so that in the calculation process there are usually certain items that are missed for the purpose of the relevant Annual Tax Letter so that from cross checks between the tax calculation carried out by the taxpayer himself and the tax service office $X$, there is a difference or deficiency that must be paid to the tax office by the person concerned. For this reason, the local tax office will issue an underpaid tax assessment letter.

\section{Tax Assessment Letter Overpaid}

The Tax Overpayment Assessment in question is the Self Assessment method, the taxpayer is given and entrusted by law to calculate his own tax so that in the calculation process there are usually certain items that are missed to be included in the relevant Annual Tax Letter so that from cross checks between the tax calculation carried out by the taxpayer himself and the tax service office $X$ there is a difference or overpayment which may be caused by a miscalculation of the taxpayer's non-taxable income or other matters relating to tax incentives that may be provided by the taxpayer. Law, while taxpayers do not know about it.

For this reason, an Overpaid Tax Assessment Letter will be issued which will later be refunded by way of restitution.

a. Meanwhile, from the results of research that the author did at the Tax Service Office $X$, the dominant factors that cause tax disputes include:

b. Lack of understanding of taxpayers about the tax rules themselves which include a lack of understanding of the procedures for filling out the Annual Tax Letter, the procedures for calculating non-taxable income, by way of deductions. 
c. The lack of counseling related to the mechanism for filling out the Annual Tax Letter, how to withhold taxes and others related to this is also a factor that also determines the existence of the tax dispute. (Results of Interview with Mr. I Md. Darma, Head of General and Internal Compliance Subdivision, October 11, 2018). From the data that the authors obtained during the conduct of interviews and research at the tax service office $\mathrm{X}$, the authors obtained data on the number of tax disputes that occurred in the 2017 period:

a) Quarter I: January - March, the number of disputes caused by business entities is 150 cases, while the number of disputes caused by individuals is 180 cases.

b) Quarter II: April - June, the number of disputes caused by business entities is 30 cases, while the number caused by individuals is 90 cases.

c) Quarter III: July - September, the number of disputes caused by business entities is 25 cases, while the number of disputes caused by individuals is 20 cases.

d) Quarter IV: October - December, the number of disputes caused by business entities was 35 cases, while the number caused by individuals was 22 cases.

\section{Tax Dispute Resolution Process}

Before entering the tax dispute resolution process at the tax court, the taxpayer will first go through the process of filing objections by the taxpayer, as well as tax audits and investigations, after the tax auditors conduct field inspections then the Director General of Taxes issues a decision. Based on the decision, if the taxpayer is not satisfied, he can file an appeal to the tax court.

\section{Taxpayer Rights}

Although there is no generally accepted definition of taxpayer rights, it is safe to say that what is meant by taxpayer rights belongs to the taxpayer or other people whose interests are in tax law. The term taxpayer rights is very rich in meaning. The term is used in a variety of contexts, including political, economic, behavioral, and relational contexts, to describe the standard legal definition. Taxpayer rights in the context of compliance, the possible categorization could cover five scenarios, which have different perspectives and produce very different results. The five approaches are:

1. From the point of view of politicians using the term to support certain policies and regulations that are driven by politics.

2. Government reviewers and government treasury departments often use the term to support a mix of economic regulation and politically driven regulation.

3. From the point of view of courts and legal systems usually have strict legal interpretations of rights and their application to taxation.

4. From the point of view of tax administration in all its forms, the term is often used to frame the way in which the administrative rules of the taxation system are implemented and interpreted.

5. From the point of view of tax administrators, ombudsmen and taxpayers also use the term to describe service standards, behavior and content aspects of the relationship between taxpayers and tax administration. (Bentley, 2015)

The rights of taxpayers are closely related to human rights. The concept of human rights and their protection has a significant influence on the notion of taxpayer rights. Human rights should be taken into account as a starting point for the analysis of taxpayer rights. (Brzeziński, 2015:4). At the International Fiscal Association seminar on 'Taxation and Human Rights' there have been attempts to begin linking taxpayers' rights with their broader legal rights. This strand of thought gave rise to significant research and debate on how to develop legal and administrative rights to protect taxpayers. At the same time, the tax authorities during the 1980s 
have conducted significant research and analysis showing the importance of taxpayers' perceptions of fairness, trust, transparency and due process to taxpayer voluntary compliance. (Bentley, 2015:4).

The rights of taxpayers have been formulated by tax experts and international organizations. Recognition and protection of the rights of taxpayers is carried out by countries in the form of a formal acknowledgment that is determined by review either in the law or other legislation, and/or in administrative documents. In the UK, New Zealand and Australia were the first countries to adopt the "Taxpayer's Charter" as a tool to assist taxpayers and inform them of their rights. The formulation of the rights of taxpayers is not all contained in the form of a charter or document, but also contained in the constitution, agreements and legislation, administrative standards, service standards, but all of them will be more effective if supported by law. (Bentley, 2015:3)

Australia applies the recognition of the rights of its taxpayers in the form of recognition of the wills and is a relationship of rights and obligations for tax authorities and taxpayers.

\section{RESEARCH METHODOLOGY}

This study uses qualitative research methods with a juridical-sociological research approach. Nasution, N. R. (2020). Data consists of two types, namely primary and secondary data. Primary data were collected through interviews with a number of respondents.

All of them are residents of Purwosari village. In addition, interviews were also conducted on: the Head of the Tax Extensification Section at the X Tax Service Office, and Mrs. Dewi, the Tax Service Section at the X Tax Service Office; Waskon Section; Tax Extensification Section Staff; UN Functional Officer and Staff of Reduction and Objection Section at Kanwil X.

Secondary data includes, among others, official documents, books, research results in the form of reports and so on." Bisinglasi, n. P.E. (2018). Secondary data or written data used in research can be in the form of: First, Legislation, namely Law Number 12 of 1994 concerning Land and Building Tax, DGT Regulation Number PER-16/PJ/2010; Second, books and literature related to Legal Protection for Taxpayers; Third, documents and archives related to Legal Protection for Taxpayers. Model Data analysis in this study was carried out after the researchers conducted interviews, observations and documentation, the researchers directly analyzed the data that had been obtained in the field, the data analysis process was carried out in stages during the research period (Ashshofa 2007: 66; Moleong 2006: 280).

\section{RESULT AND DISCUSSION}

The role and function of the Tax Service Office $\mathrm{X}$ is the same as that of the Tax Service Office in general. In accordance with Law Number 12 of 1994 concerning Land and Building Taxes, furthermore Mrs. Ningsih as Head of the Tax Extensification Section explained as follows: First, Tax Service Office X only accepts files for filing Taxpayers' objections; Second, the Tax Service Office $X$ forwards the file for filing the objection to the Regional Office of the Directorate General of Taxes in accordance with the flow of the settlement of the objection; Third, after the Regional Office of the Directorate General of Taxes has completed it, then the Tax Service Office adjusts the database.

He explained about the file for filing a Taxpayer's objection that must be fulfilled in order to fulfill the formal and material requirements. The first intended objection file that must be fulfilled is a period of 3 (three) months after the Taxpayer receives the Tax Return and/or Tax Assessment Letter; because this is a formal requirement, except in a state of necessity, the taxpayer must be able to prove that the period of 3 (three) months cannot be fulfilled. the second letter of application for filing an objection written in the Indonesian language which includes 
the identity of the Taxpayer, the reason for the Taxpayer to file an objection such as an error in the inclusion of the tax object area or class determination.

The same thing was said by Dewi. According to him, PBB taxpayers can file an objection based on the tax return and/or tax assessment letter with clear reasons stated in the objection letter, and first submitted through the Service Section, then proceed to the Waskon after that it is transferred to the Regional Office of the Directorate General. Tax. Here the role of the Tax Service Office X is only to submit the file to the Regional Office of the Directorate General of Taxes and the Regional Office of the Directorate General of Taxes to decide. Here the role of the Tax Service Office $X$ is only to receive the objection file which will be transferred to the Regional Office of the Directorate General of Taxes for further processing. And for database adjustment, after the Regional Office of the Directorate General of Taxes issues a decision in the form of refusing, accepting part or all of it and adding part or all of it, Tax Service Office $X$ then adjusts the new database after the objection decision is made. So the role and function of the Tax Service Office $\mathrm{X}$ is only as a bridge between the PBB Taxpayer and the Regional Office of the Directorate General of Taxes in the event of an objection. Objection submission is one of the rights owned by taxpayers, especially those discussed in this thesis are PBB or Land and Building Tax, in accordance with Law Number 12 of 1994 concerning Land and Building Tax. and Appeal. The implementation of the rights of PBB Taxpayers cannot be separated from the reach of legislation because considering Article 1 (3) of the Constitution which reads "The State of Indonesia is a State of Law" then the Rights of PBB Taxpayers must also be based on law as protection so that in practice -There is no deviation in the rights of the PBB Taxpayer. According to Article 15 of Law Number 12 of 1994 concerning Land and Building Tax, explains that objections can be filed on the basis of Tax Returns Payable and/or Tax Assessments, and furthermore on objections to PBB are regulated in the Regulation of the Directorate General of Taxes Number Per-16/PJ /2010 concerning procedures for filing and settling Land and Building Tax objections.

The process for submitting PBB objections from the results of interviews conducted by the author states that: Taxpayers of PBB in submitting objections must describe the reasons according to the interpretation and opinion of the Taxpayer on the SPPT or SKP that the Taxpayer receives, the description will then be examined by the tax authorities in this case. is the ranks of the Directorate General of Taxes or abbreviated as DGT.

For PBB objections can be submitted individually or collectively, with the basic provisions of submission, namely SPPT and/or SKP for individual submissions, while the submission of objections on the basis of SPPT is used for collective submissions. Each of them can attach a statement letter from the kelurahan and specifically the submission of objections is collectively submitted to the kelurahan for which the kelurahan will then submit it to the KPP Pratama concerned. The person concerned here means covering the working area of KPP Pratama. It is different again with the submission of objections made by public bodies, such as submitting an annual tax return, attaching a profit and loss balance, showing evidence of damaged buildings if necessary, giving reasons that the company has collapsed, for example, and other things that can be used as a compelling reason to file a claim. object. This is very necessary because it is possible that the value of the PBB imposed is also large.

Tax Advisory Council The settlement of tax disputes was initially carried out by the Tax Advisory Council in charge of examining and deciding tax disputes. The position of the Tax Advisory Council can be seen from before and during the enactment of Law no. 5 of 1986 concerning the State Administrative Court (Saidi, 2007). Before the Law no. 5 of 1986 concerning the State Administrative Court, the Tax Advisory Council is an auditing and tax dispute resolution body covering state taxes and local taxes. The Tax Advisory Council was a substitute for Raad Van Beroep voor Belastingzaken which was formed by the Dutch East Indies government to resolve tax disputes between the Dutch East Indies government and the 
land of the sons who were taxpayers. MPP's position is as an objection and appeal agency in tax disputes. As an objecting agency, it decides in the first instance in tax disputes, while as an appeals agency it decides for the second and final agency. In the case of an appeal, the first agency to settle the dispute is the official who makes the review and assessment of the tax assessment. Only if he is not satisfied with the official's decision can he appeal to the MPP.

Law No. 5 of 1986 concerning the State Administrative Court which was ratified and promulgated on December 29, 1986, became effective in 1991 based on Government Regulation no. 7 of 1991. In Law no. 5 of 1986 concerning the State Administrative Court, it is regulated that the Tax Advisory Council is not a tax judicial body but only functions as an administrative effort. Therefore, the Tax Advisory Council is only considered as part of an administrative effort, which means that its decision does not have permanent legal force so that it can be contested. The decision of the Tax Advisory Council is a state administrative decision so that it can be appealed to the high court of state administration (Saidi, 2007).

The Tax Advisory Council which is authorized to examine and decide on tax disputes is considered as an administrative appeal because the Tax Advisory Council is not a Tax Court that examines and decides on Tax disputes as referred to in Article 27 paragraph (1) of Law no. 6 of 1983 concerning General Provisions and Tax Procedures (Saidi, 2007). The affirmation that the Tax Advisory Council is not a judicial body that gives decisions at the highest and final level in the settlement of tax disputes but only as part of the administrative efforts contained in the explanation of Article 48 paragraph (1) of Law no. 5 of 1986 concerning the State Administrative Court, which confirms as follows: Administrative effort is a procedure that can be taken by a person or civil legal entity if he is not satisfied with a state administrative decision. The procedure is carried out in a self-governing environment and takes two forms. In the event that the settlement must be carried out by a superior agency and another agency from which issued the decision in question, the procedure is called an "administrative appeal".

The Tax Dispute Settlement Agency as the executor of Article 23 paragraph (2) and Article 27 of Law no. 9 of 1994 concerning Amendments to Law no. 6 of 1983 concerning General Provisions and Tax Procedures, on 23 May 1997 Law no. 17 of 1997 concerning the Tax Dispute Settlement Agency. This Law came into effect on January 1, 1998. At that time the Tax Dispute Settlement Agency was formed to administer justice in the tax sector, both state and local taxes, including customs and excise. The position of the Tax Dispute Settlement Agency is not the executor of the Judicial Powers. The position of the Tax Dispute Settlement Agency is the Tax Court which examines and decides on tax disputes without culminating in the Supreme Court, in other words BPSP's position is outside the judicial system as regulated in the 1945 Constitution and Law no. 17 of 1970 concerning Judicial Powers (Saidi, 2007).

The position of the Tax Court is regulated in Article 2 of Law no. 14 of 2002 concerning the Tax Court stipulates that "The Tax Court is a judicial body that exercises judicial power for taxpayers or tax insurers seeking justice for tax disputes." In this provision, it is not stated at all that the Tax Court is included in one of the 4 (four) existing judicial environments. So that there is a blurring of the position of the Tax Court in the Justice System in Indonesia. But on the other hand Law no. 9 of 2004 concerning amendments to Law no. 5 of 1986 concerning the State Administrative Court provides recognition of the position of the tax court which is a special court within the environment of the State administrative court, this can be found in the Elucidation of Article 9A which reads: "What is meant by "specialization" is differentiation or specialization in the environment of the state administrative court, for example the Tax Court."

The Tax Court is a special court, the specificity can be seen in its form as follows (Ahmadi, 2006): 1) The tax court has its own procedural law to organize a tax court; 2) Settlement of tax disputes requires special judges who have expertise in taxation and have a law degree or other degree; 3) Disputes that are processed in the Tax Court specifically relate to tax disputes and 4) The decision of the tax court contains a determination of the amount of 
tax payable from the taxpayer in the form of a technical calculation of taxation. This is done so that the taxpayer directly obtains legal certainty about the amount of tax imposed on him.

According to Sjachran Basach to distinguish between State Administrative Courts with General Courts, Religious Courts, and Military Courts is attribution. Attribution is a rounded authority, which can be either vertical attribution or horizontal attribution (Basach, 1989). Vertical attribution is the unanimous and inherent authority of one type of court to another type of court that has a higher position in stages. While horizontal attribution is the unanimous and inherent authority of one type of court to other courts that have the same level position. On this basis, to distinguish between the State Administrative Courts and the General, Religious, and Military Courts and to determine whether a judicial body is included in the State Administrative Court, the horizontal attribution benchmark of the State Administrative Court is used. This horizontal attribution benchmark can be used as an approach to the question of whether the tax court is included in the state administrative court or not. The benchmarks for horizontal attribution from the State Administrative Court consist of benchmarks for subjects and the origin of the dispute.

The benchmarks for the subject of state administrative justice can be found in several provisions regulated by Law no. 5 of 1986 concerning the State Administrative Court as described below: Article 1 point 4, namely: "State administrative disputes are disputes that arise in the field of state administration between individuals or civil legal entities and state administrative bodies or officials, both at the center and in the regions as a result of the issuance of state administrative decisions, including employment disputes based on statutory regulations. So that the subject of a state administrative dispute is between a person or civil legal entity and a state administrative body or official. Then the benchmark subject of the Tax Court can be seen in the provisions of Article 1 number 5, Law no. 14 of 2002 concerning the Tax Court, namely: "A tax dispute is a dispute that arises in the field of taxation between a Taxpayer or Tax Insurer and an authorized official as a result of the issuance of a decision that can be appealed or sued to the Tax Court based on tax laws and regulations, including lawsuits. on the implementation of collection based on the Law on Tax Collection by Forced Letter". Thus the benchmark of the subject or the parties to the dispute in tax disputes is between the people (taxpayers and tax bearers) and the government (Asmara, 2006).

Thus, if the State Administrative Court is compared with the Tax Court, the similarities can be seen. Judging from the subject of the dispute, both bring together elements of the government and elements of the people. Judging from the origin of the dispute, both are about concrete decisions from government institutions aimed at individuals, which in the legal field are often referred to as statutes (beschikking). In this case, the decision is felt to be detrimental to the people as individuals. The difference is that the Tax Court specializes in decisions in the area of taxation. Based on the analysis based on the similarity between the benchmark of the subject and the base of the dispute between the Tax Court and the State Administrative Court, the tax court is normatively part of the State Administrative Court. The Tax Court is within the State Administrative Court as a specialty. The existence of a special court within the State Administrative Court is made possible by Article 9A of Law no. 9 of 2004, which states that "In the environment of the State Administrative Court, specializations can be made which are regulated by law."

\section{CONCLUSIONS AND SUGGESTIONS}

From the description of the discussion that has been stated above, the conclusions that can be drawn on the two problems discussed are:

That legal protection for taxpayers in tax disputes and tax bearers through the Tax Court based on Law no. 14 of 2002 concerning the Tax Court is carried out in the form of the use of the rights of the taxpayer and the tax guarantor related to the Tax Court, namely in the form of 
filing a claim for rights in the form of an appeal or lawsuit, while against the decision of the Tax Court there is no known legal remedy for appeal and cassation, but only permitted through judicial review. Although this is seen as reducing the rights of taxpayers in an effort to seek justice, it is based on justifiable reasons.

\section{REFERENCES}

Abduh, A. (2019). Settlement of Tax Disputes Through Objection Agencies. Execution, 1(2).

Advianto, L. H. S. (2018). Legal Recognition and Protection of Taxpayer Rights in the Indonesian Tax Law System. Simposium Nasional Keuangan Negara, 1(1), 398-416.

Ali, Chidir, 1993, Elementary Tax Law, Eresco, Bandung. Ahmadi, Wiratni, 2006, Legal Protection for Taxpayers in Tax Dispute Resolution, PT Refikaaditama, Bandung. Asmara,

Arifuddin, A., Widhiyanti, H. N., \& Susilo, H. (2017). Juridical Implications for Land Deed Making Officials Recipient of Authorization to Deposit Income Tax/Duty on Acquisition of Land and Building Rights from Taxpayers. Jurnal Ilmiah Pendidikan Pancasila Dan Kewarganegaraan, 2(1), 18-25.

Bisinglasi, N. P. E. (2018). Legal Protection of Taxpayers Against Decision Letters of Objection in Regional Tax Disputes. (Doctoral Dissertation, Universitas Airlangga).

Bisinglasi, N. P. E. (2018). Taxpayer Legal Protection Against Decision Letter of Objection in Tax Dispute. Jurnal Media Hukum Dan Peradilan, 5(1), 153-165.

Cesariyanto, B. P. (2012). Legal Protection for Taxpayers in Filing Land and Building Tax Objections Pajak. Unnes Law Journal, 1(1), 20-28.

Firmansyah, H. (2018). Legal Protection of Brands: A Guide to Understanding the Legal Basis of Use and Protection of Brands. Media Pressindo.

Galang, 2006, Peradilan Pajak \& Lembaga Penyanderaan (Gijzeling) Dalam Hukum Pajak Di Indonesia, Laks Bang Pressindo, Yogyakarta. Basach, Sjachran, 1989, Eksistensi Dan Tolok Ukur Badan Peradilan Administrasi Di Indonesia, Alumni, Bandung. Hadjon, Philipus M, 1987, Perlindungan Hukum Bagi Rakyat Indonesia, PT Bina Ilmu, Surabaya. Mertokusumo, Sudikno, 1971, Sejarah Peradilan Dan Perundang-Undangan Di Indonesia Sejak Tahun 1942 Dan Apakah Kemanfaatnya Bagi Kita Bangsa Indonesia, Kilat Maju, Bandung, 1971.

Hakim, t. R. (2013). Perlindungan Hukum Bagi Wajib Pajak Restoran Di Kota Surabaya (Doctoral Dissertation, Universitas Airlangga).

Ispriyarso, B. (2015). Tax Hostage as a Coercive Tool in Collection of Tax Debt (Study on Tax Law Enforcement Through Tax Hostage). Masalah-Masalah Hukum, 44(1), 69-77.

Lestari, D. (2018). Perlindungan Hukum Terhadap Wajib Pajak dalam Penyelesaian Sengketa Pajak Air Permukaan di Sumatera Utara \{Studi Kasus Pajak Air Permukaan PT Indonesia Asahan Aluminium (Persero)\}.

Maz, H. (2019). Settlement of Tax Disputes in Overcoming Obstacles That Arise in Settlement of Tax Disputes. Gema Genggong: Jurnal Hukum, Keadilan \& Budaya, 2(1). 
Nasution, N. R. (2020). Perlindungan Hukum Terhadap Wajib Pajak Dalam Mekanisme Keberatan Pajak Berdasarkan PERMENKEU No. 202/PMK 03/2015 (Doctoral Dissertation, UMSU).

Rochaeti, E. (2014). Legal Protection for Taxpayers in Settlement of Tax Disputes. Jurnal Wawasan Yuridika, 26(1), 497-510.

Saidi, Muhammad Djafar, 2007, Perlindungan Hukum Wajib Pajak Dalam Penyelesaian Sengketa Pajak, PT Raja Grafmdo Persada,Jakarta. Sumertayasa, Kewenangan Penyelesaian Sengketa Pajak, Kertha Wicaksana, Vol. 13, No. 2,Juli 2007.

Subekti, Muhammad Sukri \& Djumadi, 2007, Menyelesaikan Sengketa Melalui Pengadilan Pajak, PT Elex Media Komputindo,Jakarta. Sunggono, Bambang, 2005, Metodelogi Penelitian Hukum, Cet.7, PT Raja Grafmdo Persada, Jakarta.

Sumadi, I. K., \& Noviari, N. (2014). Perlindungan Hukum Wajib Pajak Dan Penanggung Pajak Dalam Sengketa Pajak (Perspektif Uu No. 14 Tahun 2002). Jurnal Ilmiah Akuntansi Dan Bisnis, 9(2).

Sumantry, D. (2011). Reformasi Perpajakan Sebagai Perlindungan Hukum Yang Seimbang Antara Wajib Pajak Dengan Fiskus Sebagai Pelaksanaan Terhadap Undang-Undang Perpajakan. Jurnal Legislasi Indonesia, 8(1), 13-28.

Undang-Undang Dasar Negara Republik Indonesia Tahun 1945 Undang-Undang Republik Indonesia No. 6 Tahun 1983 Tentang Ketentuan Umum Dan Tata Cara Perpajakan

Undang-Undang No. 14 Tahun 1985 Tentang Mahkamahagung.

Undang-Undang No. 5 Tahun 1986 Tentang Peradilan Tata Usaha Negara.

Undang-Undang No. 6 Tahun 1983 Tentang Ketentuan Umum Dan Tata Cara Perpajakan Wardah, Sri Dan Bambang Sutiyoso, 2007, Hukumacara Perdata Dan Perkembangannya Di Indonesia, Gama Media, Yogyakarta 